\title{
THE BLOOD CONSTITUENTS IN ACUTE RHEUMATISM BEFORE AND AFTER SALICYLATE TREATMENT
}

\author{
BY
}

EVELYN M. HICKMANS, M.Sc., Ph.D.,

and

SYDNEY H. EDGAR, M.Sc., Ph.D.

(From the Children's Hospital, Birmingham.)

In a monograph by Hanzlik ${ }^{1}$ on the action and uses of salicylate and cincophen in medicine, the effect of these drugs on the blood and on nitrogen metabolism is discussed. While he shows that there is some disagreement between the early workers, later work supports the view that salicylate increases the excretion of uric acid and indeed of total nitrogen. Thus Dennis ${ }^{2}$ in 1915 showed that after a dose of 7 grains or more of sodium salicylate administered to thirteen subjects on a purin-free dietary, and suffering from different conditions, there was a definite increase of uric acid excretion with a simultaneous decrease in the uric acid content of the blood. In the same paper, Hanzlik wrote, "The kidney is affected by salicyl in therapeutic and toxic doses. This is indicated by the increased permeability to uric acid and possibly other metabolites, . . . by the changes in urine output, morphology and functional efficiency and by albuminuria.' And again, ' . . . full therapeutic doses of sodium salicylate diminish the diuresis in rheumatic and non-rheumatic individuals. .. . The diminution in renal functional efficiency was indicated by an increase in urea of the blood, a decrease in the excretion of phenol-sulphonephthalein and by albuminuria occurring simultaneously with the decrease in urine output.'

It is well known that albuminuria and also a benign type of hæmorrhagic nephritis occur occasionally in the course of acute rheumatism. Since sodium salicylate is used so extensively in treatment, it is important to determine as accurately as possible whether in children the effects on the blood and on the urinary excretion of therapeutic doses continued for a long period of time are similar to those quoted above. Also whether any albuminuria or nephritis that may occur in the course of the disease is due to the effect of the salicylate or is the result of the acute rheumatic infection.

1. The nitrogen compounds of the blood during treatment with salicylate.It was decided in the first place to determine the blood-nitrogen figures in cases of acute rheumatism during treatment with salicylate, and to compare them on the one hand with healthy school children living a normal life, and on the other, with cases of definite acute nephritis. 
For the purposes of this comparison, we have classified the cases of acute rheumatism as follows :-

(1) Chorea.

(2) Rheumatism without chorea.

(a) With carditis.

(b) Without carditis.

Acute nephritis has been divided into hæmorrhagic and hydræmic forms.

Since the nitrogen constituents of the blood are to some extent affected by food, the specimens were nearly all taken fasting (before breakfast). A series of figures for normal children of similar ages, some of which have already been published $^{3}$, is given in Table 1 .

TABLE 1.

BLOOD FIGURES FOR NORMAL CHILDREN.

\begin{tabular}{|c|c|c|c|c|c|c|c|c|c|}
\hline & & & & & & $\begin{array}{l}\text { No. of } \\
\text { estimations }\end{array}$ & $\begin{array}{c}\text { Min. } \\
\text { mgrm \% }\end{array}$ & $\begin{array}{c}\text { Max. } \\
\text { mgrm. \% }\end{array}$ & $\begin{array}{c}\text { Mean } \\
\text { mgrm. \% }\end{array}$ \\
\hline Calcium.. & .. & .. & .. & . & . & 13 & $10 \cdot 2$ & $11 \cdot 5$ & $10 \cdot 65$ \\
\hline Phosphorus & .. & .. & $\cdots$ & . & $\cdots$ & 12 & 4.02 & $5 \cdot 29$ & $4 \cdot 47$ \\
\hline Urea $\quad$. & . & . & .. & . & . & 18 & $20 \cdot 7$ & $40 \cdot 0$ & $26 \cdot 9$ \\
\hline Non-protein I & N. & .. & . & .. & . & 16 & $23 \cdot 6$ & $36 \cdot 8$ & $27 \cdot 8$ \\
\hline Creatinine & . & . & .. & .. & $\cdots$ & 12 & $1 \cdot 09$ & $1 \cdot 64$ & $1 \cdot 32$ \\
\hline Amino-acid $\mathrm{N}$ & & .. & .. & . & $\cdots$ & 17 & $6 \cdot 08$ & $9 \cdot 52$ & $8 \cdot 32$ \\
\hline Uric acid & $\therefore$ & .. & .. & .. & $\cdots$ & 20 & 1.95 & $4 \cdot 14$ & 3.03 \\
\hline Chlorides & .. & .. & .. & . & $\cdots$ & 14 & 445 & 523 & 490 \\
\hline
\end{tabular}

(a) UREA. Table 2 gives the blood-urea figures found for the groups as classified above. The mean figure for 41 cases of all types of rheumatism under treatment is $\mathbf{3 5 . 8} \mathrm{mgrm}$. per cent., and the various classes show practically little variation. The mean of 18 determinations on healthy school children was $26.9 \mathrm{mgrm}$. per cent., with a range of 21 to $40 \mathrm{mgrm}$. per cent., while acute nephritis cases gave much higher figures. Whilst the blood urea appears to be a little higher in rheumatic children under treatment with salicylate than in normal children, yet it is still (except in a few instances) within the accepted normal range.

The non-protein nitrogen values follow those of urea, the mean in acute rheumatism being $37 \cdot 1$, and in the healthy controls $27.8 \mathrm{mgrm}$. per cent.

(b) URIC ACID. (See Table 3.) While the various groups in the rheumatic cases vary very little, the mean of 24 estimations was 2.56 as against $2.88 \mathrm{mgrm}$. per cent. for 7 cases of acute nephritis and $3.03 \mathrm{mgrm}$. per cent. for 20 normal healthy children, the latter showing a range of 1.95 to $4 \cdot 14$. The blood in acute rheumatism therefore appears to be fairly normal as regards uric acid, tending rather towards the lower limit. 
TABLE 2.

BLOOD UREA IN RHEUMATISM DLRING TREATMENT WITH SALICYLATE AND IN NEPHRITIS.

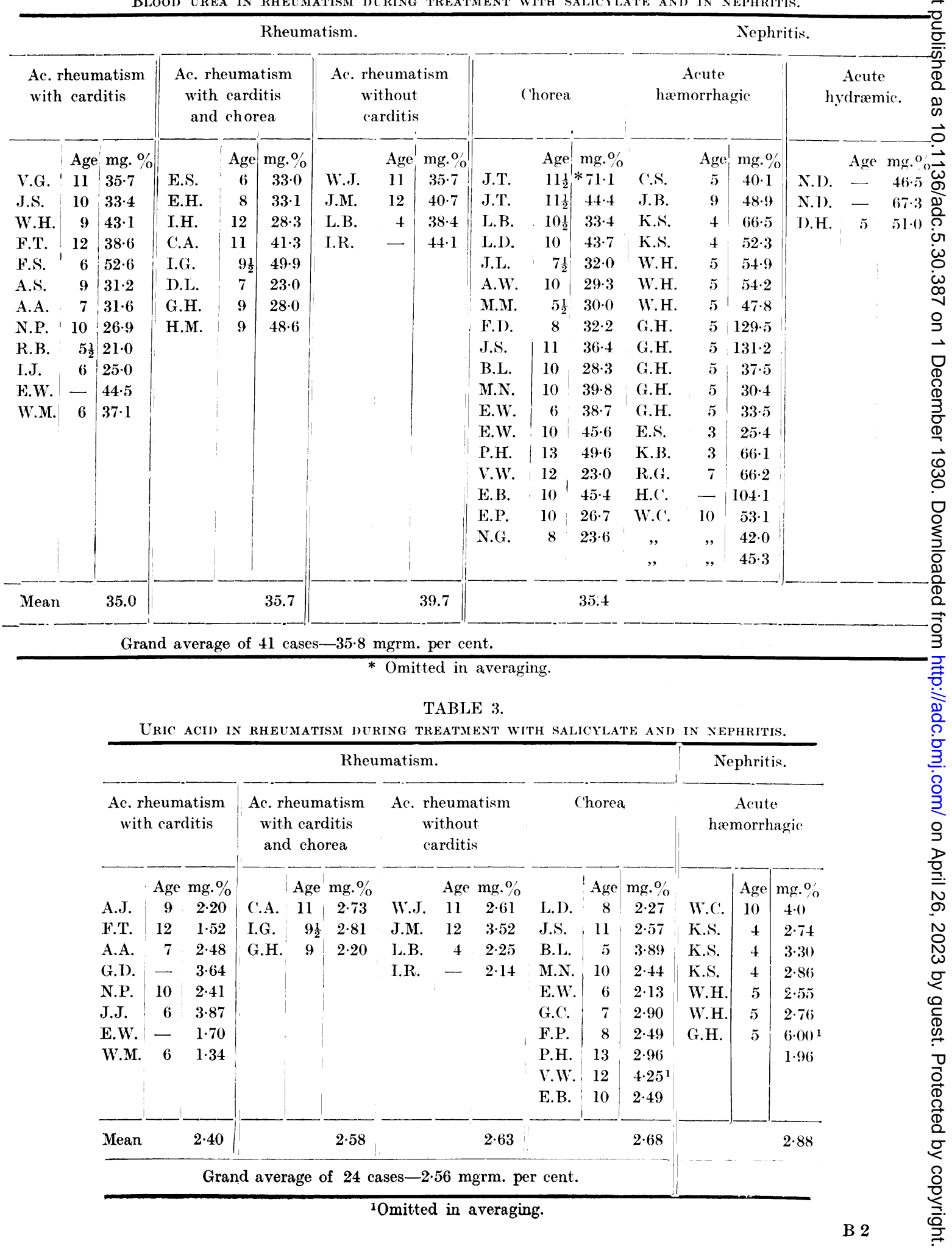


TABLE

Amino-ACId Nitrogen aNd CREatinine (Marm. PER Cent.) IN

\begin{tabular}{|c|c|c|c|c|c|c|c|c|c|c|c|}
\hline & & & & & & eumati & m. & & & & \\
\hline \multicolumn{4}{|c|}{$\begin{array}{l}\text { Asute rheumatism } \\
\text { with carditis }\end{array}$} & \multicolumn{4}{|c|}{$\begin{array}{l}\text { Acute rheumatism } \\
\text { with carditis } \\
\text { and chorea }\end{array}$} & \multicolumn{4}{|c|}{$\begin{array}{l}\text { Acute rheumatism } \\
\text { without carditis }\end{array}$} \\
\hline & Age & AAN & Creat. & & Age & Å̈N & Creat. & & Age & AAN & Creat. \\
\hline C. & 11 & - & $1 \cdot 30$ & E.H. & 8 & - & $1 \cdot 21$ & W.J. & 11 & $8 \cdot 64$ & 1.40 \\
\hline V.G. & 11 & - & $1 \cdot 18$ & I.H. & 12 & $7 \cdot 81$ & $1 \cdot 31$ & J.M. & 12 & 8.46 & 1.52 \\
\hline J.S. & 10 & $7 \cdot 18$ & 1.87 & C.A. & 11 & $6 \cdot 85$ & 1.06 & L.B. & 4 & $9 \cdot 93$ & 1.57 \\
\hline W.H. & 9 & 8.52 & - & I.G. & $9 \frac{1}{2}$ & $9 \cdot 03$ & $1 \cdot 34$ & I.R. & - & $9 \cdot 85$ & - \\
\hline A.J. & 9 & $9 \cdot 40$ & - & D.L. & 7 & $6 \cdot 36$ & $1 \cdot 09$ & & & & \\
\hline F.T. & 12 & $10 \cdot 40$ & 1.55 & G.H. & 9 & $7 \cdot 73$ & $1 \cdot 17$ & & & & \\
\hline F.S. & 9 & 一 & 1.44 & H.M. & 9 & $9 \cdot 21$ & 1.53 & & & & \\
\hline A.A. & 7 & $8 \cdot 33$ & - & -.T. & 7 & $9 \cdot 67$ & $1 \cdot 47$ & & & & \\
\hline G.D. & - & $5 \cdot 69$ & - & & & & & & & & \\
\hline N.P. & 10 & 6.40 & - & & & & & & & & \\
\hline R.B. & $5 \frac{1}{2}$ & 8.08 & $1 \cdot 40$ & & & & & & & & \\
\hline I.J. & 6 & - & $1 \cdot 28$ & & & & & & & & \\
\hline E.W. & - & $8 \cdot 70$ & - & & & & & . & & & \\
\hline W.M. & 6 & $8 \cdot 43$ & - & & & & & & & & \\
\hline Mean & & $8 \cdot 11$ & 1.43 & & & 8.09 & 1.27 & & & $9 \cdot 22$ & 1.50 \\
\hline
\end{tabular}


4.

RHEUMATISM DURING TREATMENT WITH SALICYLATE ANI IN NEPHRITIS.

\begin{tabular}{|c|c|c|c|c|c|c|c|c|c|c|c|}
\hline & & & & \multicolumn{8}{|c|}{ Nephritis. } \\
\hline \multicolumn{4}{|c|}{ (horea } & \multicolumn{4}{|c|}{$\begin{array}{c}\text { Acute } \\
\text { hæmorrhagic }\end{array}$} & \multicolumn{4}{|c|}{$\begin{array}{c}\text { Acute } \\
\text { hydræmic }\end{array}$} \\
\hline & Age & AAN. & Creat. & & Age & AAN. & Creat & & Age & AAN. & Creat. \\
\hline J.'T. & $11 \frac{1}{2}$ & - & $1 \cdot 20$ & J.B. & 9 & $10 \cdot 50$ & $1 \cdot 66$ & N.I). & - & 一 & $1 \cdot 37$ \\
\hline J.T. & $11 \frac{1}{2}$ & - & $1 \cdot 08$ & K.S. & 4 & $7 \cdot 73$ & $1 \cdot 83$ & N.D. & - & - & $1 \cdot 15$ \\
\hline I.B. & $10 \frac{1}{2}$ & - & 1.20 & K.s. & 4 & $8 \cdot 98$ & $2 \cdot 28$ & D.H. & - & - & $1 \cdot 14$ \\
\hline L.D. & $10^{2}$ & - & $1 \cdot 27$ & K.s. & 4 & $8 \cdot 14$ & - & & & & \\
\hline J.L. & $7 \frac{1}{2}$ & $10 \cdot 0$ & $1 \cdot 34$ & W.H. & 5 & $10 \cdot 10$ & $1 \cdot 18$ & & & & \\
\hline A.W. & $10^{2}$ & $5 \cdot 20$ & 0.93 & W.H. & 5 & $8 \cdot 33$ & - & & & & \\
\hline M.M. & $5 \frac{1}{2}$ & $10 \cdot 60$ & - & W.H. & 5 & $7 \cdot 70$ & $1 \cdot 34$ & & & & \\
\hline F.D. & 8 & $6 \cdot 74$ & - & W.H. & 5 & $8 \cdot 53$ & $1 \cdot 14$ & & & & \\
\hline J.S. & 11 & $10 \cdot 1$ & - & G.H. & 5 & $10 \cdot 20$ & $1 \cdot 57$ & & & & \\
\hline B.L. & 5 & $9 \cdot 09$ & $2 \cdot 0$ & G.H. & 5 & $7 \cdot 65$ & $1 \cdot 16$ & & & & \\
\hline M.N. & 10 & $7 \cdot 65$ & $1 \cdot 23$ & G.H. & 5 & $7 \cdot 86$ & $1 \cdot 28$ & & & & \\
\hline E.W. & 6 & $9 \cdot 80$ & $1 \cdot 25$ & G.H. & 5 & 8.09 & $1 \cdot 23$ & & & & \\
\hline -.G. & 7 & $7 \cdot 31$ & $1 \cdot 17$ & E.S. & 3 & $7 \cdot 69$ & - & & & & \\
\hline G.W. & 10 & $9 \cdot \dot{03}$ & $1 \cdot 55$ & K.B. & 3 & - & $1 \cdot 62$ & & & & \\
\hline -P. & 8 & $9 \cdot 03$ & $1 \cdot 27$ & R.G. & 7 & - & $1 \cdot 45$ & & & & \\
\hline P.H. & 13 & $6 \cdot 54$ & $2 \cdot 96$ & H.C. & - & - & $1 \cdot 54$ & & & & \\
\hline V.W. & 12 & $8 \cdot 48$ & 1.23 & W.C. & 10 & $7 \cdot 37$ & $1 \cdot 36$ & & & & \\
\hline E.B. & 10 & $8 \cdot 23$ & $1 \cdot 17$ & , &, & $8 \cdot 69$ & $1 \cdot 34$ & & & & \\
\hline E.P. & 10 & - & $1 \cdot 40$ & , & , & - & 1.59 & & & & \\
\hline \multirow[t]{3}{*}{ N.G. } & 8 & $8 \cdot 09$ & $1 \cdot 13$ & , & ", & 8.05 & 1.08 & & & & \\
\hline & & ! & & ", & " " & 8.54 & & & & & \\
\hline & & $8 \cdot 27$ & $1 \cdot 32$ & & & $8 \cdot 48$ & $1 \cdot 45$ & & & & \\
\hline
\end{tabular}


Since this work was done, Folin ${ }^{4}$ has pointed out that no method at present known for the estimation of blood uric acid gives a true picture of the fluctuations ; but since our determinations were all done in the same way and with exactly similar solutions, the values are comparable.

(c) Amino-Acid nitrogen. The figures given in Table 4 are practically all reported on fasting bloods since a protein meal definitely raises the aminoacid content of the blood. In view of the fact previously reported ${ }^{5}$ that the figures obtained by Folin's method vary somewhat according to the alkalinity of the solutions, increasing with the alkalinity, comparison with figures for normal blood by the same worker and using strictly similar reagents is of great importance. The mean of the results obtained, observing these precautions, on 32 cases of rheumatism was 8.21 which compares very closely with the fasting normal of $8.32 \mathrm{mgrm}$. per cent. (The non-fasting figure was 9.15.) The aminoacid nitrogen figures in rheumatism may therefore be considered to be normal.

TABLE 5.

BLOOD AND URINE FIGURES IN RHEUMATISM BEFORE AND DURING TREATMENT With SALICyLate.

\begin{tabular}{|c|c|c|c|c|c|c|}
\hline & \multicolumn{2}{|l|}{ Case 1} & \multicolumn{2}{|c|}{ Case II } & \multicolumn{2}{|c|}{ Case III } \\
\hline & $\begin{array}{c}\text { Before } \\
\text { treatment }\end{array}$ & $\begin{array}{c}\text { After } \\
\text { treatment } \\
\text { for } 7 \text { days }\end{array}$ & $\begin{array}{c}\text { Before } \\
\text { treatment }\end{array}$ & $\begin{array}{c}\text { After } \\
\text { treatment } \\
\text { for } 4 \text { days }\end{array}$ & $\begin{array}{c}\text { Before } \\
\text { treatment }\end{array}$ & $\begin{array}{c}\text { After } \\
\text { treatment } \\
\text { for } 5 \text { days }\end{array}$ \\
\hline $\begin{array}{l}\text { Blood urea } \\
\quad, \quad \text { N.P.N. } \\
,, \quad \text { uric acid }\end{array}$ & $\begin{array}{c}34 \cdot 5 \mathrm{mg} \cdot \% \\
24 \cdot 6 \quad, \\
4 \cdot 4 \quad,\end{array}$ & $\begin{array}{c}38.5 \mathrm{mg} . \\
35.1 \\
1.95,\end{array}$ & $\begin{array}{c}37 \cdot 5 \mathrm{mg} . \% \\
30 \cdot 2, \\
3 \cdot 86,\end{array}$ & $\begin{array}{c}\text { No } \\
\text { blood } \\
\text { obtained }\end{array}$ & 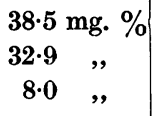 & $\begin{array}{c}41.5 \mathrm{mg} . \% \\
43.5, \\
2.9 \quad,\end{array}$ \\
\hline $\begin{array}{l}\text { Urinary output } \\
\text { per diem (grams) }\end{array}$ & $\begin{array}{l}\text { Av. of } \\
3 \text { days }\end{array}$ & $\begin{array}{l}\text { Av. of } \\
7 \text { days }\end{array}$ & $\begin{array}{l}\text { Av. of } \\
3 \text { days }\end{array}$ & $\begin{array}{l}\text { Av. of } \\
4 \text { days }\end{array}$ & $\begin{array}{l}\text { Av. of } \\
3 \text { days }\end{array}$ & $\begin{array}{l}\text { Av. of } \\
5 \text { days }\end{array}$ \\
\hline Urea $\ldots$ & $5 \cdot 06$ & 6.9 & 2.95 & $5 \cdot 22$ & $10 \cdot 36$ & $12 \cdot 48$ \\
\hline Uric Acid & $1 \cdot 11$ & $1 \cdot 78$ & $\cdot 156$ & $2 \cdot 02$ & $1 \cdot 81$ & $3 \cdot 07$ \\
\hline Ammonia & $\cdot 155$ & .087 & .089 & $\cdot 175$ & $\cdot 224$ & $\cdot 217$ \\
\hline Total N. & $3 \cdot 88$ & $3 \cdot 65$ & 1.63 & $2 \cdot 25$ & $5 \cdot 25$ & $6 \cdot 42$ \\
\hline
\end{tabular}

(d) Creatinine. The values for blood creatinine in cases of acute rheumatism, also reported in Table 4, show little difference from the normal, being 1.29 and 1.32 respectively, and the mean value for acute hæmorrhagic nephritis was $1.45 \mathrm{mgrm}$. per cent.

2. Blood urea and uric acid before and during treatment.-As nearly all cases of rheumatism admitted to hospital have already received salicylate treatment, we were fortunate recently in having three cases sent in which either had had no salicylate at all or had had none for a long time, and the opportunity was taken of determining the blood and urinary nitrogen before treatment began and again during treatment. Although it is inadvisable to draw any very definite conclusions from such a small number of observations, the figures 
obtained are recorded in Table 5. It is hoped that opportunity will occur from time to time to add to them.

These observations indicate that in the acute stages of rheumatic fever, the blood urea and non-protein nitrogen are slightly higher than the normal average, and may remain higher or even increase during treatment with salicylate. The uric acid is also high, but is reduced considerably by treatment.

3. The effect of salicylate on healthy children.-In order to see whether an increased blood urea results from the use of salicylate in the absence of a rheumatic infection, healthy children of about the same age as the patients under observation were given increasing doses of salicylate three times daily. The amount of salicylate was kept constant at each dose for about 3 to 4 days at a time. The following is a typical result :-

\begin{tabular}{|c|c|c|c|c|c|c|c|c|c|c|}
\hline \multirow{2}{*}{\multicolumn{2}{|c|}{ Before treatment }} & & & \multicolumn{7}{|c|}{ Blood urea } \\
\hline & & & $\cdots$ & . & $\cdots$ & .. & $32 \cdot 9$ & mgrm. & per & cent. \\
\hline After 5 & 5 grains, t.d.s. & $3-4$ & days & .. & $\cdots$ & .. & $31 \cdot 7$ & , & , & " \\
\hline 10 & 0 & , & ," & $\ldots$ & $\cdots$ & $\cdots$ & $24 \cdot 1$ & , & , & , \\
\hline,$\quad 15$ & , & , & , & . & . & . & $28 \cdot 0$ & " & , & , \\
\hline
\end{tabular}

It seems clear that such doses as were here given do not increase the blood urea of normal children, for a time at least. The blood urea in cases of rheumatism increased slightly in the first 3 or 4 days after treatment began.

TABLE 6.

AVERage DaILY OUTPUT OF NITROGEN BY NON-RHEUMATIC CHILDREN BEFoRE AND AFTER SALICYLATE.

\begin{tabular}{|c|c|c|c|c|c|c|c|c|}
\hline & & & \multicolumn{2}{|c|}{ Case 1.} & \multicolumn{2}{|c|}{ Case 2.} & \multicolumn{2}{|c|}{ Cáse 3.} \\
\hline \multicolumn{3}{|c|}{$\begin{array}{l}\text { Urinary output } \\
\text { grams per diem }\end{array}$} & $\begin{array}{c}\text { Before } \\
\text { salicylate }\end{array}$ & $\begin{array}{c}\text { After } \\
\text { salicylate }\end{array}$ & $\begin{array}{c}\text { Before } \\
\text { salicylate }\end{array}$ & $\begin{array}{c}\text { After } \\
\text { salicylate }\end{array}$ & $\begin{array}{c}\text { Before } \\
\text { salicylate }\end{array}$ & $\begin{array}{c}\text { After } \\
\text { salicylate }\end{array}$ \\
\hline Urea .. & .. & $\ldots$ & 8.48 & $8 \cdot 17$ & $11 \cdot 0$ & $10 \cdot 3$ & $9 \cdot 7$ & $7 \cdot 3$ \\
\hline Uric Acid & .. & .. & - & - & 一 & - & $1 \cdot 21$ & $1 \cdot 02$ \\
\hline $\mathrm{NH}_{3}$ & .. & $\ldots$ & - & - & 一 & - & $0 \cdot 120$ & $0 \cdot 105$ \\
\hline Total N & .. & .. & $4 \cdot 57$ & $4 \cdot 27$ & $6 \cdot 00$ & 5.55 & $4 \cdot 80$ & $3 \cdot 24$ \\
\hline Volume & .. & .. & - & - & - & - & $711 \mathrm{c.cm}$. & 574c.cm. \\
\hline
\end{tabular}

Other children were treated in the same way and the output of nitrogen estimated. The results are shown in Table 6, and on comparing them with those in Table 5, there appears to be little doubt that salicylate does increase the output of total nitrogen, urea and uric acid through the kidneys in rheumatism, but in normal children there seems to be no such effect. Indeed, the output of these substances shows a slight diminution rather than an increase. The kidney in acute rheumatism therefore appears to be more susceptible to the action of salicylate than the normal kidney, but so far no reason for this is apparent, nor for the fact that the blood urea continues to be high or even increased in spite of the iocreased output. 
In this investigation, the figures obtained are not sufficiently high to confirm Hanzlik's suggestion that the salicylate produces even a mild nephritis. We have not found albuminuria after its use in the cases in which the urine was examined before and after treatment with salicylate, neither have we found albuminuria present in the majority of cases observed.

4. Other observations on the blood in rheumatism.-(a) Chloride. The values for blood chloride figures were normal, being within the range found in our series of twenty-one normal children, namely, 445-523 mgrm. per cent., with a mean of 490 . The mean of 33 estimations in cases of rheumatism during treatment was $476 \mathrm{mgrm}$. per cent.

TABLE 7.

Calcium axd phosphores in rhecatatism.

\begin{tabular}{|c|c|c|c|c|c|c|c|c|c|c|c|c|c|c|c|}
\hline \multicolumn{4}{|c|}{$\begin{array}{l}\text { Ac. rheumatism } \\
\text { with carditis }\end{array}$} & \multicolumn{4}{|c|}{$\begin{array}{c}\text { Ac. rheumatism } \\
\text { with carditis } \\
\text { and chorea }\end{array}$} & \multicolumn{4}{|c|}{$\begin{array}{l}\text { Ac. rheumatism } \\
\text { without } \\
\text { carditis }\end{array}$} & \multicolumn{4}{|c|}{ Chorea } \\
\hline & Age & P. & Ca. & & Age & P. & ('a. & & Age & P. & Ca. & & Age & P. & Ca. \\
\hline$-\mathrm{C}$. & 11 & $4 \cdot 93$ & $11 \cdot 3$ & E.S. & 6 & $5 \cdot 77$ & $9 \cdot 1$ & W.J.' & 11 & - & $11 \cdot 0$ & J.T. & $11 \frac{1}{2}$ & 一 & $10 \cdot 2$ \\
\hline V.G. & 11 & - & $10 \cdot 8$ & E.H. & - & 一 & $11 \cdot 0$ & J.M. & 12 & $6 \cdot 06$ & $11 \cdot 0$ & J.T. & $11 \frac{1}{2}$ & $4 \cdot 65$ & $10 \cdot 5$ \\
\hline J.S. & 10 & $4 \cdot 70$ & $10 \cdot 9$ & A.T. & - & $4 \cdot 70$ & - & L.B. & 4 & $4 \cdot 00$ & 一 & L.B. & $10 \frac{1}{2}$ & $4 \cdot 40$ & $10 \cdot 7$ \\
\hline W.H. & 9 & - & $11 \cdot 0$ & C.A. & 11 & - & $9 \cdot 6$ & I.R. & - & $5 \cdot 06$ & $10 \cdot 0$ & L.D. & 10 & - & $9 \cdot 1$ \\
\hline A.J. & 9 & $4 \cdot 34$ & $11 \cdot 0$ & I.G. & $9 \frac{1}{2}$ & $6 \cdot 72$ & $11 \cdot 1$ & & & & & J.L. & $7 \frac{1}{2}$ & $6 \cdot 20$ & $11 \cdot 6$ \\
\hline F.S. & 9 & 一 & $10 \cdot 3$ & D.L. & 7 & 一 & $9 \cdot \tilde{5}$ & & & & & B.L. & 5 & 一 & $10 \cdot 0$ \\
\hline A.A. & 7 & 一 & $11 \cdot 7$ & O.H. & 9 & $4 \cdot 54$ & $9 \cdot 7$ & & & & & M.N. & 10 & $4 \cdot 68$ & $10 \cdot 2$ \\
\hline G.D. & 一 & 6.09 & $11 \cdot 3$ & H.M. & 9 & 一 & $10 \cdot 6$ & & & & & E.W. & 6 & $4 \cdot 88$ & $10 \cdot 1$ \\
\hline N.P. & 10 & - & $10 \cdot 5$ & & & & & & & & & E.W. & 10 & $5 \cdot 08$ & $10 \cdot 0$ \\
\hline R.B. & $5 \frac{1}{2}$ & 一 & $11 \cdot 5$ & & & & & & & & & $-\mathrm{P}$. & - & $3 \cdot 88$ & - \\
\hline I.J. & 6 & - & $11 \cdot 4$ & & & & & & & & & P.H. & 13 & $4 \cdot 94$ & $11 \cdot 3$ \\
\hline E.W. & - & $4 \cdot 10$ & - & & & & & & & & & V.W. & 12 & $4 \cdot 89$ & $11 \cdot 2$ \\
\hline W.M. & 6 & $5 \cdot 55$ & $9 \cdot 6$ & & & & & & & & & E.B. & 10 & $4 \cdot 50$ & 11.0 \\
\hline & & & & & & & & & & & & E.P. & 10 & $4 \cdot 40$ & $10 \cdot 0$ \\
\hline & & & & & & & & & & & & N.G. & 8 & $3 \cdot 94$ & - \\
\hline Mean & & 4.95 & $10 \cdot 94$ & & & $5 \cdot 43$ & $10 \cdot 1$ & & & $5 \cdot 04$ & $10 \cdot 3$ & & & $4 \cdot 70$ & $10 \cdot 4$ \\
\hline
\end{tabular}

Grand Averages :-Calcium $-10.56 \mathrm{mgrm}$. per cent. Phosphorus $=4.98$ mgrm. per cent.

(b) Calcium. The average figure for calcium in the cases here recorded is $10 \cdot 56 \mathrm{mgrm}$. per cent., while a larger range of 59 cases of all clinical types of rheumatism gave an average of $10.6 \mathrm{mgrm}$. per cent. The figures in the various classes do not differ widely. Thirteen determinations on healthy school children of about the same age and of the same social class gave an average of $10 \cdot 65$ mgrm. per cent.

Pearson and Wyllie $^{6}$ contend that the type of child which develops rheumatism is an acid or hypercalcic child, in whom the calcium and phosphorus 
are present in excess in the tissues making them acid, while the blood is apparently normal. Parsons and Edgar in a paper recently published ${ }^{7}$ showed $^{-}$ that the $\mathrm{pH}$ of the blood is normal, even in the acute cases during treatment. Under these conditions the blood calcium indicates indirectly the ionic calcium, and since the figures given here show that the blood calcium is normal, the ionic calcium must be normal too. Since also the content of the blood plasma indicates the blood changes which are occurring at the same time within the cells, our results show that we cannot consider the rheumatic child to be hypercalcic or hyperacidic.

The calcium figures in the various clinical types of rheumatism do not differ widely. Warners has recently stated that in chorea the serum calcium is low and rises as the chorea subsides. Our average figure for the groups of children with chorea differs so little from that for our whole group of rheumatic cases and from our normal figure that we consider it falls within normal limits, and although Warner's results show that serum calcium rises as the chorea improves, yet none of his figures is outside the limits of the normal.

(c) Phosphorus. It is well known that inorganic phosphorus is substantially less in adult life than in childhood, so that comparison with a series of normal children of the same age is important. The results we have obtained gave a mean figure for phosphorus in acute rheumatism of 4.98 as compared with a mean of $4.47 \mathrm{mgrm}$. per cent. in normal children. Since the excretion of urea and phosphorus runs a more or less parallel course it would seem that here is some confirmation of the suggestion that the kidney in rheumatism is not able to excrete urea or phosphorus in sufficient quantities to reduce the amount of these in the blood to a normal level. The mean of 16 specimens from cases of acute glomerular nephritis was $4 \cdot 76 \mathrm{mgrm}$. per cent.

\section{Summary and conclusions.}

Three cases of acute rheumatism before salicylate treatment was commenced showed blood urea, non-protein nitrogen and uric acid somewhat higher than the figures obtained for normal children of the same age.

Although salicylate increases the output of total nitrogen, urea and uric acid through the kidneys, and the blood uric acid is thereby decreased, the examination of a large number of cases of rheumatism during treatment indicates that the blood urea and non-protein nitrogen still remain slightly higher than normal during treatment ; and since the blood phosphorus is also slightly higher than normal, it would seem that the kidney in rheumatism is unable to deal adequately with these two products. That this inability is due to some impairment of renal efficiency as a result of the acute rheumatic infection rather than to the salicylate, is suggested by the fact that the blood urea of normal children was not found to be increased by similar quantities of salicylate. On the other hand, considering that after salicylate treatment, blood urea reaches a higher level than before salicylate is given, it is possible that salicylate may increase to some extent the degree of renal inefficiency. 
We would express our indebtedness to Prof. Leonard G. Parsons for valuable help and criticism throughout this research.

Our thanks are also due to the Medical Research Council for a grant covering the expenses of this investigation and for a personal grant to one of us (E. M. H.).

\section{REFERENGES.}

1. Hanzlik, P. J., Medicine, Baltimore, 1926, V, 197.

2. Dennis, J., (Quoted by Hanzlik).

3. Edgar, S. H., Birmingham Med. Rev., Birmingham, 1929, IV, 16.

4. Folin O., J. Biol. Chem., N.Y., 1930, 86, 179.

5. Edgar, S. H., Biochem. J., Cambridge, 1928, XXII, 162.

6. Pearson, W. J. \& Wyllie, W. C., Recent Advances in Padiatrics, Lond., 1928.

7. Parsons, L. G. \& Edgar, S. H., Arch. Dis. Child., Lond., 1929, IV, 291.

8. Warner, E. C., Lancet, Lond., 1930, ii, 339. 